\title{
Preparation and characterization of hierarchical USY by post-treatment
}

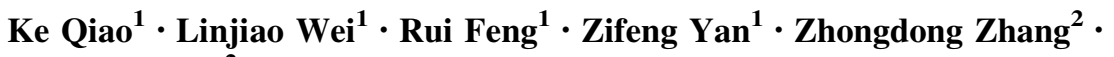 \\ Xionghou $\mathrm{Gao}^{2}$
}

Received: 6 May 2015/ Accepted: 29 June 2015/Published online: 9 July 2015

(C) The Author(s) 2015. This article is published with open access at Springerlink.com

\begin{abstract}
Two modifying agents, citric acid and EDTA$2 \mathrm{Na}$, were used to modify USY zeolite to obtain the hierarchical USY with high crystallinity. XRD, $\mathrm{N}_{2}$ isothermal sorption, ${ }^{27} \mathrm{Al}$ and ${ }^{29} \mathrm{Si} \mathrm{NMR}$, and TEM were adopted to characterize the dealumination process in the post-treatment of USY. The results showed that all modified USY have increased surface areas and pore volume due to the removal of non-framework $\mathrm{Al}$ species. Besides, framework dealumination occurred in the modification process. USYEC, which was modified by the combined effects of citric acid and EDTA-2Na, has the highest $\mathrm{SiO}_{2} / \mathrm{Al}_{2} \mathrm{O}_{3}$ ratio of 19.40 and relatively high crystallinity.
\end{abstract}

Keywords USY zeolite - Mesopore - Crystallinity · EDTA-2Na $\cdot$ Citric acid

\section{Introduction}

Zeolite-containing catalysts have been playing important roles in oil refining and petrochemical fields [1]. Crystalline aluminosilicate $\mathrm{Y}$ zeolite has typical microporous structure and three-dimensional channels. Due to its

Zifeng Yan

zfyancat@upc.edu.cn

Rui Feng

feng2007115@163.com

1 State Key Laboratory of Heavy Oil Processing, Key Laboratory of Catalysis, China University of Petroleum, Qingdao 266580, People's Republic of China

2 Lanzhou Petrochemical Research Center, China National Petroleum Corporation, Lanzhou 730060,

People's Republic of China adjustable acidity, high surface area, and thermal/hydrothermal stabilities, Y zeolite has been widely used in many reactions such as fluid catalytic cracking (FCC) [2], hydrocracking [3], alkylation [4] and desulfurization [5]. However, with the crude oil supplies becoming severe and inferior, the micropore of conventional $\mathrm{Y}$ zeolite set severe limitation on the diffusion of large-molecule reactants and products [6]. Moreover, the porthole is easily blocked up with the bigger molecules in severe and inferior feedstock, which deactivates the FCC catalyst quickly and reduces the conversion of feedstock. Nanosized zeolite and hierarchical (i.e., micro-, mesoporous) materials can substantially increase the external surface area and shorten the diffusion path length in micropores $[7,8]$. Therefore, various strategies have been developed to obtain extra-large-pore zeolites [9, 10], nanosized zeolites [11-13] and hierarchical zeolites [14-16]. For Y zeolite, two approaches have been developed to obtain hierarchical structures, involving direct synthesis using dual templates [17] and post-treatment of $Y$ zeolite by desilication or dealumination using acid or alkali. Hierarchical Y zeolite by acid dealumination has enhanced thermal/hydrothermal stabilities along with the extraction of $\mathrm{Al}$ atoms from zeolite lattices [18, 19]. In contrast, desilication of $\mathrm{Y}$ zeolite by alkali can generate enough defects and rich mesoporosity in inner zeolite [20]. Various acid and basic agents such as phosphoric acid, citric acid, ammonium fluorosilicate and $\mathrm{NaOH}$ have been adopted to modify $\mathrm{Y}$ and ZSM-5 zeolites in our previous studies [21-24]. However, one obvious drawback of posttreatment is the great reduction of crystallinity which decreases the structural stability. Therefore, it is a challenge to generate more mesopores on $\mathrm{Y}$ zeolite while maintaining its high crystallinity. In this study, the combined action of citric acid and ethylenediaminetetraacetic acid disodium salt (EDTA-2Na) was adopted to modify 
Fig. 1 XRD patterns of parent USY and modified USY (a) and peak shift of ( $\left.\begin{array}{llll}5 & 3 & 3\end{array}\right)$ lattice plane (b) (a)

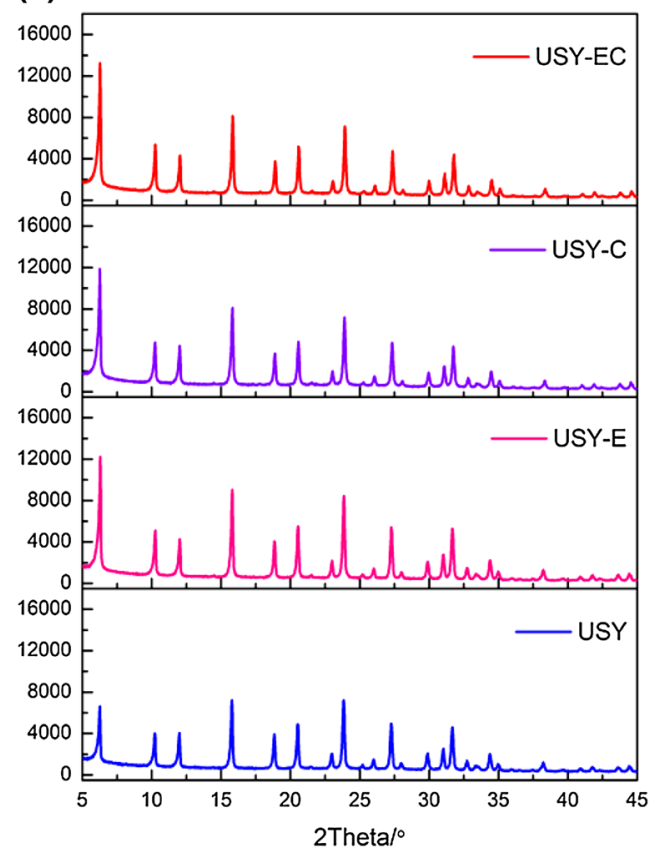

(b)

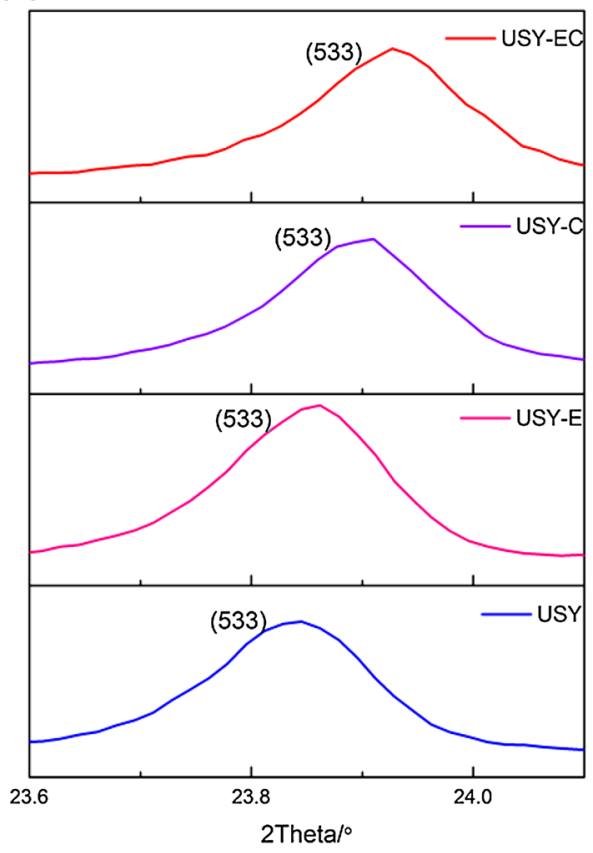

USY zeolite to create hierarchical USY with high surface area.

\section{Experimental section}

\section{Raw materials}

A commercial available USY was purchased from Zibo Huaxing Powder Co. Ltd. and its bulk $\mathrm{SiO}_{2} / \mathrm{Al}_{2} \mathrm{O}_{3}$ was 5.9 (derived from $\mathrm{XRF}$ analysis). Citric acid $\left(\mathrm{C}_{6} \mathrm{H}_{8} \mathrm{O}_{7}, \mathrm{AR}\right)$ and ethylenediaminetetraacetic acid disodium salt $\left(\mathrm{C}_{10} \mathrm{H}_{14} \mathrm{~N}_{2}\right.$ $\mathrm{Na}_{2} \mathrm{O}_{8} \cdot 2 \mathrm{H}_{2} \mathrm{O}$, EDTA-2Na, AR) were purchased from Sinopharm Chemical Reagent Co. Ltd.

\section{Preparation of hierarchical USY}

$5.0 \mathrm{~g}$ of parent USY zeolite was treated with $50 \mathrm{~mL}$ of modifier-containing aqueous solution at $80{ }^{\circ} \mathrm{C}$ for $4 \mathrm{~h}$ under stirring. EDTA-2Na solution $(0.2 \mathrm{~mol} / \mathrm{L})$, citric acid solution $(0.2 \mathrm{~mol} / \mathrm{L})$, and a complex solution of EDTA$2 \mathrm{Na}(0.1 \mathrm{~mol} / \mathrm{L})$ and citric acid $(0.1 \mathrm{~mol} / \mathrm{L})$ were separately adopted to modify USY. The suspension was then filtered and washed with deionized water. Hierarchical USY was finally obtained after the drying of the filtering cake at $110^{\circ} \mathrm{C}$ overnight. Three USY samples were marked as USY-E, USY-C, and USY-EC corresponding to modifiers EDTA-2Na, citric acid, and complex modifiers of EDTA-2Na and citric acid.

\section{Characterization}

$\mathrm{X}$-ray diffraction (XRD) patterns were recorded on a Bruker AXS diffractometer (Germany) using $\mathrm{Cu}-\mathrm{K} \alpha$ radiation operating at $40 \mathrm{kV}$ and $40 \mathrm{~mA}$, scanning from $5^{\circ}$ to $45^{\circ}$ and at a speed of $0.01 \% \mathrm{~s} . \mathrm{N}_{2}$ isothermal sorption was measured at $-196{ }^{\circ} \mathrm{C}$ on Micrometrics TRISTAR 3000 analyzer. The samples were outgassed at $300{ }^{\circ} \mathrm{C}$ for $4 \mathrm{~h}$ at vacuum pressure prior to $\mathrm{N}_{2}$ sorption measurement.

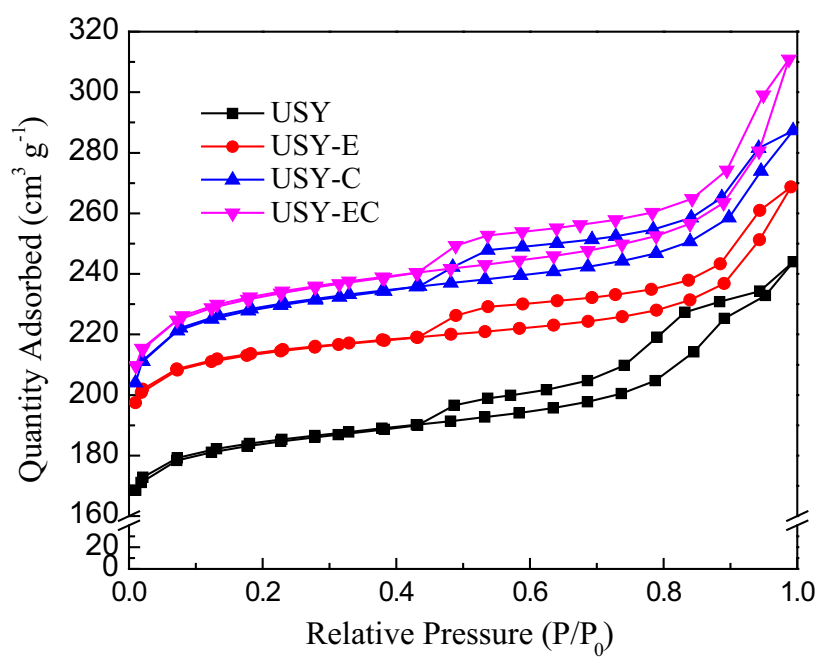

Fig. $2 \mathrm{~N}_{2}$ adsorption-desorption isotherms of parent USY and posttreated USY samples 
Specific surface area was calculated by the BrunauerEmmett-Teller (BET) method using experimental points in the relative pressure range of $0.05-0.25$. Solid-state nuclear magnetic resonance (NMR) experiments were performed using Bruker Advance III 400 spectrometer at resonance frequencies $104.0 \mathrm{MHz}$ for ${ }^{27} \mathrm{Al}$ and ${ }^{29} \mathrm{Si}$. The Bruker
$4.0 \mathrm{~mm}$ MAS probe was used for acquisition of $10 \mathrm{kHz}$ spectra. The single-pulse sequence with rf-pulse duration of $0.3 \mu \mathrm{s}\left(\pi / 20^{\circ}\right)$ and recycling time of $0.3 \mathrm{~s}$ was used. Transmission electron microscopy (TEM) images were acquired on a JEOL JEM 2100 electron microscope operated at an accelerating voltage of $200 \mathrm{kV}$.

Table 1 Textural and physiochemical properties of USY

\begin{tabular}{|c|c|c|c|c|c|c|c|c|}
\hline \multirow[t]{2}{*}{ Sample } & \multicolumn{3}{|c|}{ Surface area $\left(\mathrm{m}^{2} \mathrm{~g}^{-1}\right)$} & \multicolumn{3}{|c|}{ Pore volume $\left(\mathrm{cm}^{3} \mathrm{~g}^{-1}\right)$} & \multirow[t]{2}{*}{ Crystallinity $^{\mathrm{d}}(\%)$} & \multirow[t]{2}{*}{$\mathrm{Si} / \mathrm{Al}^{\mathrm{e}}$} \\
\hline & $\mathrm{S}_{\mathrm{BET}}^{\mathrm{a}}$ & $\mathrm{S}_{\text {micro }}^{\mathrm{b}}$ & $\mathrm{S}_{\text {meso }}^{\mathrm{c}}$ & $\mathrm{V}_{\text {total }}$ & $\mathrm{V}_{\text {micro }}^{\mathrm{b}}$ & $\mathrm{V}_{\text {meso }}^{\mathrm{c}}$ & & \\
\hline USY & 563 & 493 & 87 & 0.38 & 0.25 & 0.13 & 67.1 & 15.60 \\
\hline USY-E & 653 & 584 & 80 & 0.42 & 0.30 & 0.12 & 78.5 & 14.60 \\
\hline USY-C & 697 & 607 & 101 & 0.44 & 0.31 & 0.14 & 66.0 & 19.00 \\
\hline USY-EC & 709 & 598 & 110 & 0.48 & 0.31 & 0.17 & 66.8 & 19.40 \\
\hline
\end{tabular}

${ }^{a}$ Calculated by the BET method

${ }^{\mathrm{b}}$ Calculated by the t-Plot method

c Calculated by the BJH method

${ }^{\mathrm{d}}$ Measured by XRD

e Measured by NMR

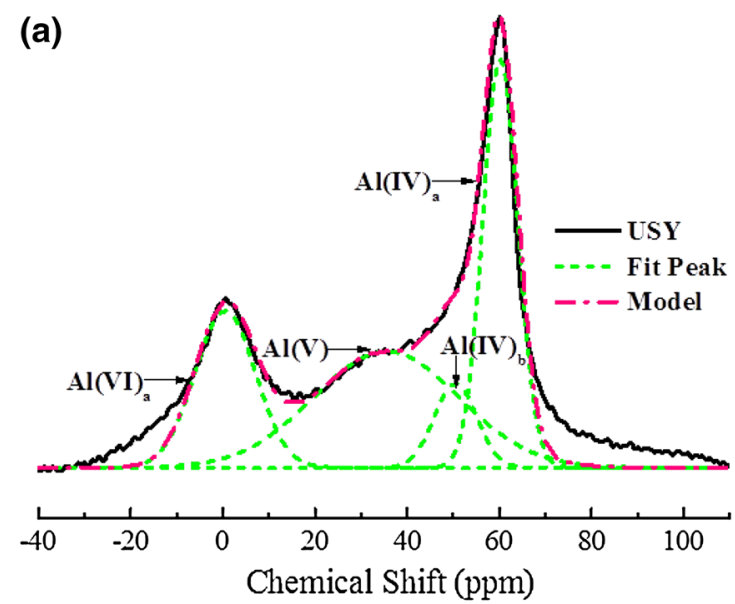

(c)

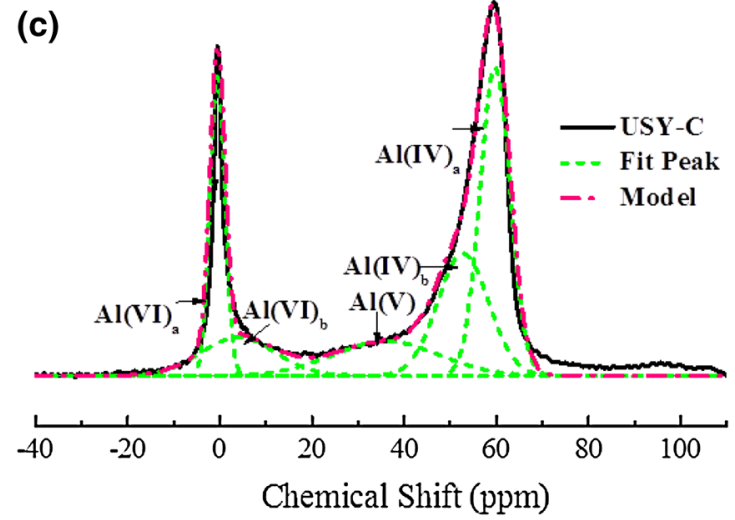

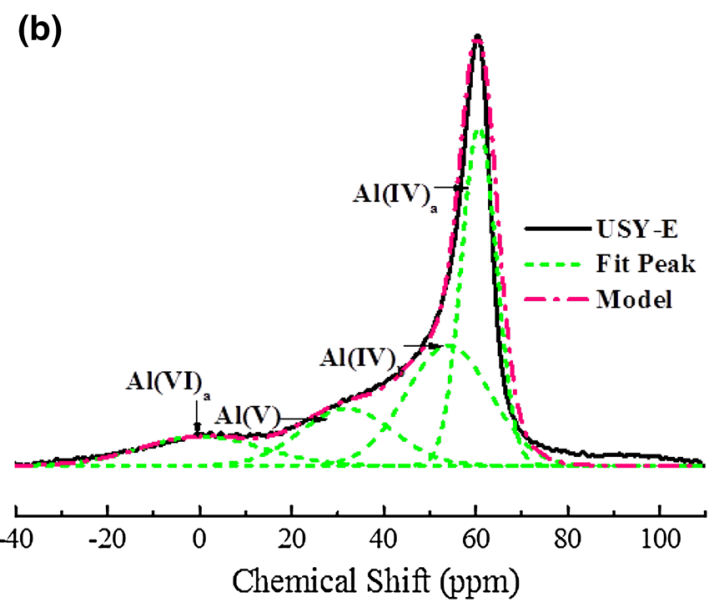

(d)

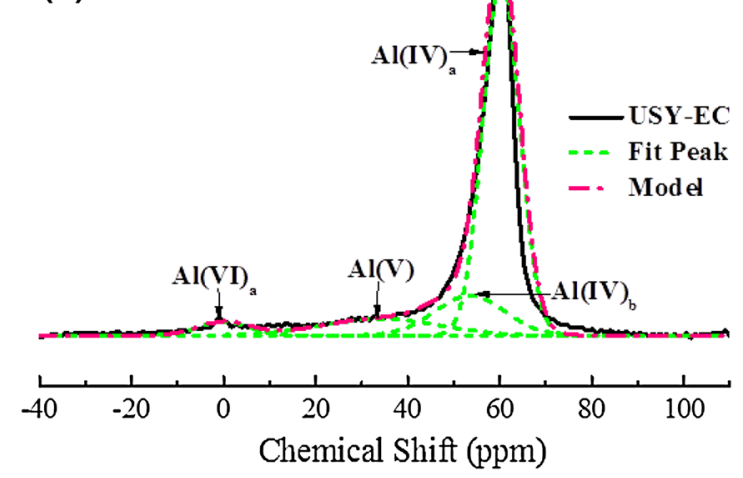

Fig. $3{ }^{27}$ Al MAS NMR spectra of samples: a USY, b USY-E, c USY-C, and d USY-EC 


\section{Results and discussion}

XRD patterns show that all samples possess the faujasite $Y$ phase (Fig. 1a) and the intensities of characteristic peaks rarely change. The calculation results from XRD analysis show that USY-E has higher crystallinity, while USY-C and USY-EC have slightly lower crystallinities compared with parent USY. It is ascribed to the removal of nonframework aluminum species. Besides, the peak positions of faujasite Y phase of modified USY shift to higher degree compared with parent USY. Figure $1 \mathrm{~b}$ shows the peak position shift of THE (533) lattice plane. It means that the unit cell size of USY becomes smaller. It may be ascribed to the dealumination of framework aluminum by modifying agents, since THE bond length of $\mathrm{Al}-\mathrm{O}(1.75 \AA)$ is bigger than $\mathrm{Si}-\mathrm{O}(1.61 \AA)$. It coincides with the $\mathrm{SiO}_{2} /$ $\mathrm{Al}_{2} \mathrm{O}_{3}$ derived from NMR results below.

$\mathrm{N}_{2}$ isothermal sorption in Fig. 2 shows that all samples have typical IV-type curves with wide hysteresis loop indicative of mesoporous structures. The results in Table 1 show that the total surface area and micropore surface area of modified USY increase largely, while mesopore surface area of USY-C and USY-EC increase slightly compared with THE parent USY. Pore volumes have the same trends as above. It is worth nothing that only USY-EC has the highest increases of mesopore surface area and mesopore volume. It indicates that the combination effect of two modifiers on dealumination is more effective to clear microporous channels and generate secondary mesopores than one modifying agent.

${ }^{27} \mathrm{Al}$ and ${ }^{29} \mathrm{Si}$ NMR were used to analyze the coordination modes of framework $\mathrm{Si}$ and $\mathrm{Al}$ atoms (Figs. 3, 4). To discuss the changes of $\mathrm{Al}$ species, the peak were deconvoluted into the four types of $\mathrm{Al}$ fragments (Fig. 3). The resonance peak at $60 \mathrm{ppm}$ is assigned to framework tetra-coordinated $\mathrm{Al}\left(\mathrm{Al}(\mathrm{IV})_{\mathrm{a}}\right)$. The tail resonance peak at $\sim 50 \mathrm{ppm}$ is marked as $\mathrm{Al}(\mathrm{IV})_{\mathrm{b}}$, but its assignment is unclear [16, 25-28]: (1) distorted tetra-coordinated framework $\mathrm{Al}$ atoms, (2) penta-coordinated aluminum species, and (3) non-framework four-coordinated Al species. The resonance peak at $\sim 35 \mathrm{ppm}$ is attributed to nonframework penta-coordinated $\mathrm{Al}$ species $(\mathrm{Al}(\mathrm{V}))$. The resonance peaks at $\sim 0 \mathrm{ppm}$ are attributed to extra framework hexa-coordinated $\mathrm{Al}$ species $\left[\right.$ both $\mathrm{Al}(\mathrm{VI})_{\mathrm{a}}$ and
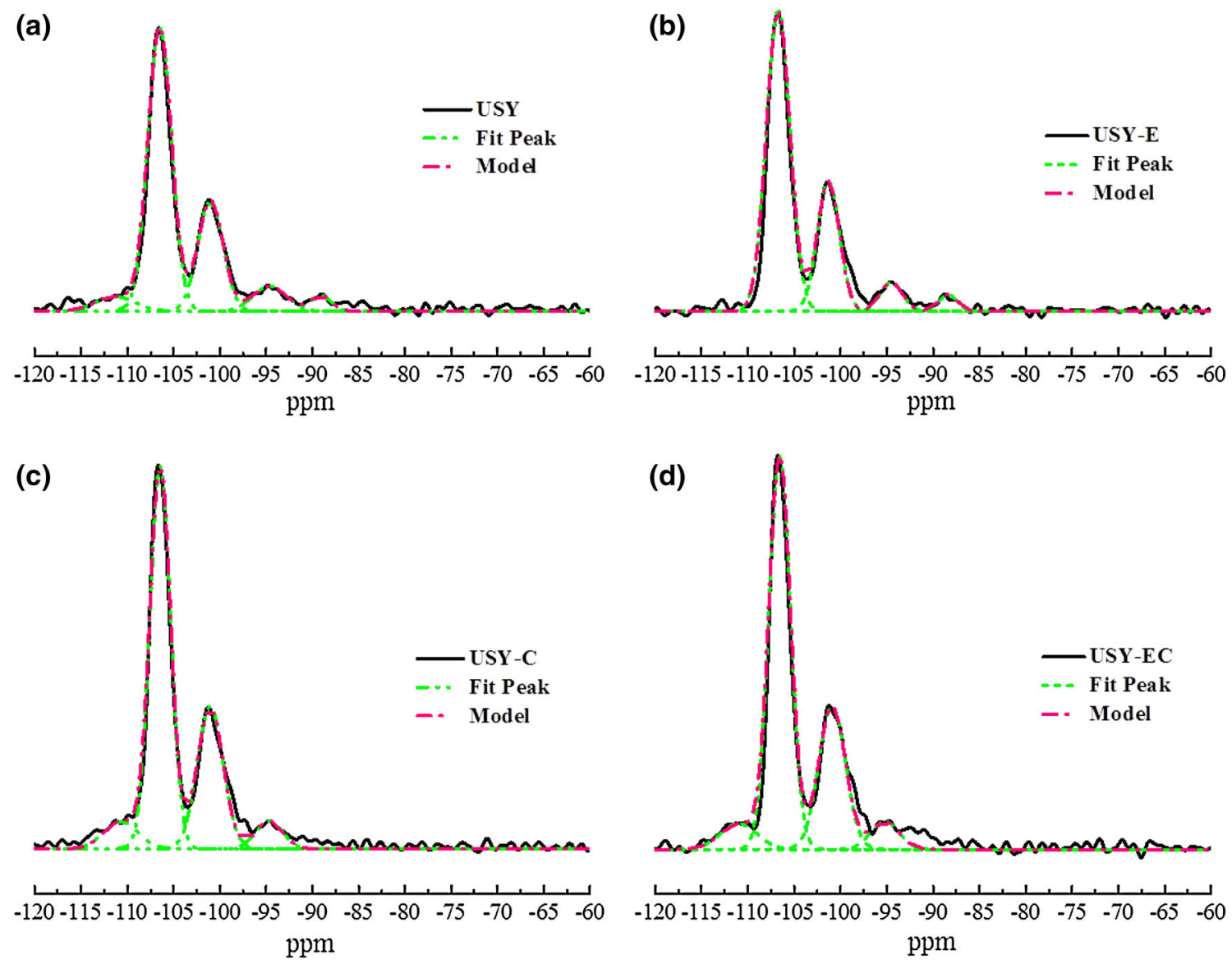

Fig. $4{ }^{29}$ Si MAS NMR spectra of samples: a USY, b USY-E, c USY-C, and d USY-EC 
$\left.\mathrm{Al}(\mathrm{VI})_{\mathrm{b}}\right]$. It is obvious that the peaks of $\mathrm{Al}(\mathrm{VI})_{\mathrm{a}}, \mathrm{Al}(\mathrm{VI})_{\mathrm{b}}$, and $\mathrm{Al}(\mathrm{V})$ of modified USY decrease largely compared with the parent USY. It is consistent with the increases of surface areas and pore volumes (Table 1) which can be attributed to the removal of non-framework fragments after post-treatment of USY. The comparison of USY-C and USY-E shows that citric acid contributes to the removal of $\mathrm{Al}(\mathrm{V})$ atoms, while EDTA-2Na contributes to the removal of $\mathrm{Al}(\mathrm{VI})$ atoms. It is known that EDTA is an important complex agent and it is easy to combine with metal ions such as $\mathrm{Al}^{3+}$ (shown in Scheme 1) Besides, it is clear that almost all $\mathrm{Al}$ atoms of USY-EC are in the tetra-coordinated framework Al states, indicating that the modification of USY combining with citric acid and EDTA-2Na is more effective to remove non-framework dealumination compared with that with modifier alone.

It is well known that there are four kinds of $\mathrm{Si}-\mathrm{Al}$ coordination states depending on the number of $\mathrm{Si}$ atom connected to $\mathrm{Al}$ atoms via bridged oxygen atom [29]. In ${ }^{29} \mathrm{Si}$ NMR spectra, a set of broad signals can be deconvoluted into four peaks at $-106,-101,-94$, and -89 ppm which in turn correspond to silicon environments of $\mathrm{Q}^{4}(\mathrm{Si}(0 \mathrm{Al})), \mathrm{Q}^{3-}$ $(\mathrm{Si}(1 \mathrm{Al})), \mathrm{Q}^{2}(\mathrm{Si}(2 \mathrm{Al}))$, and $\mathrm{Q}^{1}(\mathrm{Si}(3 \mathrm{Al}))$. However, two dominant peaks at -106 and $-101 \mathrm{ppm}$ are observed in Fig. 4, indicating all samples possess $Q^{4}$ and $Q^{3}$ silicon environments. By calculation from ${ }^{29} \mathrm{Si}$ NMR spectra, the framework $\mathrm{SiO}_{2} / \mathrm{Al}_{2} \mathrm{O}_{3}$ ratios of modified USY are higher than the parent USY. USY-EC has the highest $\mathrm{SiO}_{2} / \mathrm{Al}_{2} \mathrm{O}_{3}$ ratio of 19.40, indicative of the effective effects of complex modifying agents on framework dealumination. Another line centered at lower than $-110 \mathrm{ppm}$ is assigned to $\mathrm{Si}(4 \mathrm{Si})$ of silica which belongs to the amorphous silica [30].

An analysis of the ${ }^{27} \mathrm{Al}$ and ${ }^{29} \mathrm{Si}$ NMR spectra shows that USY-E has a lower proportion of non-framework $\mathrm{Al}(\mathrm{VI})$ than USY-C (Fig. 3) and the former has undetected amorphous silica (Fig. 4). It indicated that non-framework dealumination occurred on USY-E, while both nonframework and framework dealumination occurred on USY-C, leading to the higher crystallinity of USY-E than USY-C (Table 1. Similarly, the degree of non-framework dealumination of USY-EC is higher than USY-C, which results in higher crystallinity for the former (Table 1).
Scheme 1 Complexation action of EDTA-2Na with $\mathrm{Al}^{3+}$ ions<smiles></smiles>

EDTA-2Na

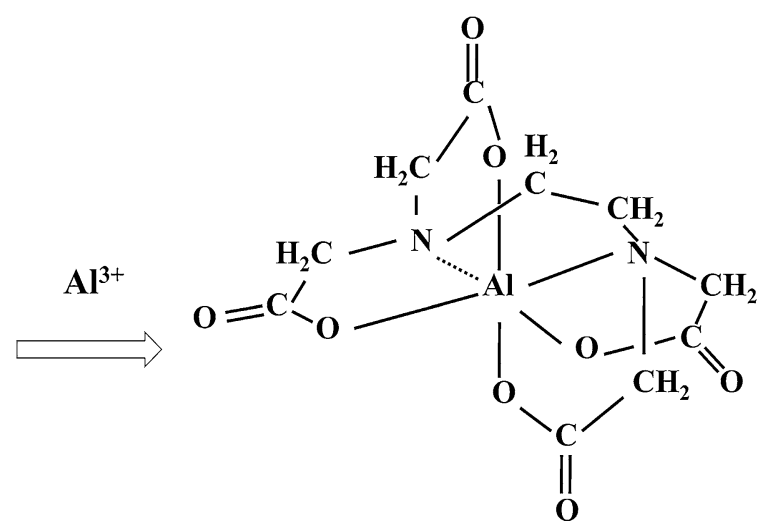

$\mathrm{Al}^{3+}$ migration
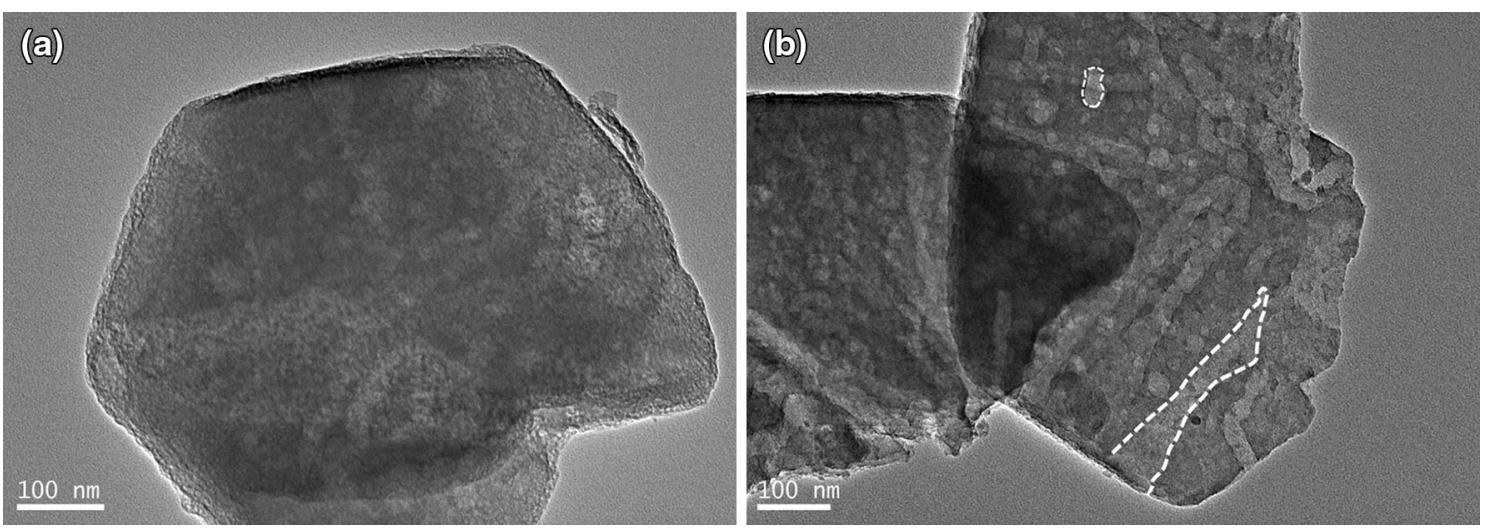

Fig. 5 TEM images of a parent USY and b USY-EC 
The pore-creating effects of modifying agents on USY were further verified by TEM analysis. The TEM images in Fig. 5 show that some cavities and holes form after modification consistent with the increase of pore volumes. More mesopores are generated on USY-EC than USY, but no damage to the monolithic structure is observed.

\section{Conclusion}

An effective method was introduced to obtain hierarchical USY zeolite with high surface area and crystallinity using both citric acid and EDTA-2Na. The results show that modifying agents improve the surface areas and pore volumes due to both non-framework dealumination and framework dealumination. Citric acid has better dealumination effect than EDTA-2Na to generate mesopores; however, the latter has better migrating effect for $\mathrm{Al}$ fragments and does not destroy the zeolite structure. Combining the dealumination effect and migration of $\mathrm{Al}$ species, the hierarchical USY with improved mesoporosity and relatively high crystallinity was obtained using two agents together.

Acknowledgments This work was financially supported by the PetroChina Refinery Catalyst Key Project (Project No. 2013A-2106) and the Joint Funds of the National Natural Science Foundation of China and China National Petroleum Corporation (Grant No. U1362202).

Open Access This article is distributed under the terms of the Creative Commons Attribution 4.0 International License (http:// creativecommons.org/licenses/by/4.0/), which permits unrestricted use, distribution, and reproduction in any medium, provided you give appropriate credit to the original author(s) and the source, provide a link to the Creative Commons license, and indicate if changes were made.

\section{References}

1. Vermeiren W, Gilson JP (2009) Impact of zeolites on the petroleum and petrochemical industry. Top Catal 52:1131-1161

2. Cerqueira HS, Caeiro G, Costa L, Ribeiro FR (2008) Deactivation of FCC catalysts. J Mol Catal A: Chem 292:1-13

3. Shimada H, Sato K, Honna K, Enomoto T, Ohshio N (2009) Design and development of Ti-modified zeolite-based catalyst for hydrocracking heavy petroleum. Catal Today 141:43-51

4. Anand R, Khaire SS, Maheswari R, Gore KU (2004) Alkylation of biphenyl with t-butylalcohol over modified Y zeolites. J Mol Catal A: Chem 218:241-246

5. Tian F, Shen Q, Fu Z, Wu Y, Jia C (2014) Enhanced adsorption desulfurization performance over hierarchically structured zeolite Y. Fuel Process Technol 128:176-182

6. Ruthven DM (2001) Post, Chapter 12 Diffusion in zeolite molecular sieves. In: van Bekkum EMFPAJH, Jansen JC (eds) Studies in Surface Science and Catalysis pp 525-577
7. Lopez-Orozco S, Inayat A, Schwab A, Selvam T, Schwieger W (2011) Zeolitic materials with hierarchical porous structures. Adv Mater 23:2602-2615

8. Perez-Ramirez J, Christensen CH, Egeblad K, Christensen $\mathrm{CH}$, Groen JC (2008) Hierarchical zeolites: enhanced utilisation of microporous crystals in catalysis by advances in materials design. Chem Soc Rev 37:2530-2542

9. Corma A, Diaz-Cabanas MJ, Jorda JL, Martinez C, Moliner M (2006) High-throughput synthesis and catalytic properties of a molecular sieve with 18 - and 10-member rings. Nature 443:842-845

10. Přech J, Kubů M, Čejka J (2014) Synthesis and catalytic properties of titanium containing extra-large pore zeolite CIT-5. Catal Today 227:80-86

11. Yin X, Chu N, Yang J, Wang J, Li Z (2014) Synthesis of the nanosized MCM-22 zeolite and its catalytic performance in methane dehydro-aromatization reaction. Catal Commun 43:218-222

12. Abrishamkar M, Izadi A (2013) Nano-ZSM-5 zeolite: synthesis and application to electrocatalytic oxidation of ethanol. Microporous Mesoporous Mater 180:56-60

13. Awala H, Gilson JP, Retoux R, Boullay P, Goupil JM, Valtchev V, Mintova S (2015) Template-free nanosized faujasite-type zeolites. Nat Mater 14:447-451

14. Yuan E, Tang Z, Mo Z, Lu G (2014) A new method to construct hierarchical ZSM-5 zeolites with excellent catalytic activity. J Porous Mater 21:957-965

15. Zhu Y, Hua Z, Zhou J, Wang L, Zhao J, Gong Y, Wu W, Ruan M, Shi J (2011) Hierarchical mesoporous zeolites: direct selfassembly synthesis in a conventional surfactant solution by kinetic control over the zeolite seed formation. Chem-A Eur J 17:14618-14627

16. Van Aelst J, Haouas M, Gobechiya E, Houthoofd K, Philippaerts A, Sree SP, Kirschhock CEA, Jacobs P, Martens JA, Sels BF, Taulelle F (2014) Hierarchization of USY Zeolite by $\mathrm{NH} 4 \mathrm{OH}$. A Postsynthetic Process Investigated by NMR and XRD. J Phys Chem C 118:22573-22582

17. García-Martínez J, Li K, Krishnaiah G (2012) A mesostructured $\mathrm{Y}$ zeolite as a superior FCC catalyst-from lab to refinery. Chem Commun 48:11841-11843

18. Francis J, Guillon E, Bats N, Pichon C, Corma A, Simon LJ (2011) Design of improved hydrocracking catalysts by increasing the proximity between acid and metallic sites. Appl Catal A 409:140-147

19. Ishihara A, Itoh T, Nasu H, Hashimoto T, Doi T (2013) Hydrocracking of 1-methylnaphthalene/decahydronaphthalene mixture catalyzed by zeolite-alumina composite supported NiMo catalysts. Fuel Process Technol 116:222-227

20. Baojian S, Zhengxing Q, Xionghou G, Feng L, Shuge Z, Wen S, Baojie W, Hongjuan Z, Honghai L (2012) Desilication by alkaline treatment and increasing the silica to alumina ratio of zeolite Y. Chin J Catal 33:152-163

21. Li XJ, Qiao K, He L, Liu X, Yan ZF, Xing W, Qin L, Dai B, Zhang Z (2014) Combined modification of ultra-stable Y zeolites via citric acid and phosphoric acid. Appl Petrochem Res 4:343-349

22. Qiao K, Li XJ, He LF, Liu X, Yan ZF, Xing W, Qin L, Dai B, Zhang Z (2014) An efficient modification of ultra-stable Y zeolites using citric acid and ammonium fluosilicate. Appl Petrochem Res 4:373-378

23. Chang XW, He LF, Liang HN, Liu XM, Yan ZF (2010) Screening of optimum condition for combined modification of ultra-stable Y zeolites using multi-hydroxyl carboxylic acid and phosphate. Catal Today 158:198-204

24. Peng P, Wang Y, Rood MJ, Subhan F, Yan ZF, Qin L, Zhang Z, Zhang Z, Gao X (2015) Effects of the dissolution alkalinity and 
self-assembly on ZSM-5-based micro-/mesoporous composites: a study for relationship between porosity, acidity, and catalytic performance. CrystEngComm 17:3820-3828

25. Agudelo JL, Mezari B, Hensen EJM, Giraldo SA, Hoyos LJ (2014) On the effect of EDTA treatment on the acidic properties of USY zeolite and its performance in vacuum gas oil hydrocracking. Appl Catal A 488:219-230

26. Van Bokhoven JA, Roest AL, Koningsberger DC, Miller JT, Nachtegaal GH, Kentgens APM (2000) Changes in structural and electronic properties of the zeolite framework induced by extraframework Al and La in H-USY and La (x) NaY: a 29Si and 27Al MAS NMR and 27Al MQ MAS NMR study. J Phys Chem B 104:6743-6754

27. Katada N, Nakata S, Kato S, Kanehashi K, Saito K, Niwa M (2005) Detection of active sites for paraffin cracking on USY zeolite by $27 \mathrm{Al}$ MQMAS NMR operated at high magnetic field 16 T. J Mol Catal A: Chem 236:239-245

28. Malicki N, Mali G, Quoineaud AA, Bourges P, Simon LJ, Thibault-Starzyk F, Fernandez C (2010) Aluminium triplets in dealuminated zeolites detected by $27 \mathrm{Al}$ NMR correlation spectroscopy. Microporous Mesoporous Mater 129:100-105

29. Lippmaa E, Mägi M, Samoson A, Tarmak M, Engelhardt G (1981) Investigation of the structure of zeolites by solid-state high-resolution silicon-29 NMR spectroscopy. J Am Chem Soc 103:4992-4996

30. Yan Z, Ma D, Zhuang J, Liu X, Liu X, Han X, Bao X, Chang F, Xu L, Liu Z (2003) On the acid-dealumination of USY zeolite: a solid state NMR investigation. J Mol Catal A: Chem 194:153-167 